\title{
Erratum to: Corporate social responsibility reporting platforms: enabling transparency for accountability
}

\author{
Stephanie Watts
}

Published online: 28 September 2014

(C) Springer Science+Business Media New York 2014

\section{Erratum to: Inf Technol Manag \\ DOI 10.1007/s10799-014-0192-2}

The citation numbers for references from 44 to 84 should be corrected by adding one to the number of each of the citations from 44 to 84 . The citation number will then correspond to the correct reference in the Reference section.

That is, citation number 44 in the text refers to reference number 45 , citation number 45 in the text refers to reference number 46 , and so on, for all citations 44 and above.

For example, the fourth sentence in the last paragraph of section 1.1 should read as follows:

Two meta-analyses have found consistent positive relationships between CSR and financial performance [45, 57], whereas others have had neutral results, finding that firms engaging in CSR will earn the same rate of profit as those that do not [50].

Thus, the first citation in the above sentence is a reference to Margolis JD, Elfenbein HA, Walsh JP (2007) Does it pay to be good? A meta-analysis and redirection of research on the relationship between corporate social and financial performance. In: Proceed Acad of Manage, Philadelphia, PA. Pace University, New York, NY.

The one exception to this is the other two citations to number [44], which are also in the last paragraph of section 1.1. These two [44]s refer to reference listed as [44], which is the following: Margolis JD, Walsh JP (2003) Misery loves company: rethinking social initiatives by business. Admin Sci Quart 48:268-305.

The online version of the original article can be found under doi:10. 1007/s10799-014-0192-2.

S. Watts $(\bowtie)$

Department of Information Systems, Boston University School

of Management, Boston, MA, USA

e-mail: swatts@bu.edu 